\title{
HKSA secara In-Silico Senyawa 1-Benzil-3-Benzoilurea dan Analognya sebagai Penghambat Reseptor Bruton Tyrosine Kinase (BTK)
}

\author{
Denis Cristian Sudarno ${ }^{1 *}$, Farida Suhud ${ }^{1}$, Siswandono ${ }^{2}$ \\ ${ }^{1}$ Fakultas Farmasi Universitas Surabaya, Universitas Surabaya, Surabaya-Indonesia \\ * corresponding author: deniscristian1212@gmail.com
}

\begin{abstract}
In this study, a new anticancer drug design for non-Hodgkin's lymphoma was carried out, with a molecular docking approach from the compound 1-benzyl-3-benzoylurea parent and its analog as an anticancer compound. The purpose of the study was to obtain the best quantitative structure-activity relationship (QSAR). The in-silico activity test was carried out on the new 1benzyl-3-benzoilurea and its analog compound against the Bruton Tyrosine Kinase receptor (BTK) PDB code (5FBN) by using the Molegro Virtual Docker 5.5 program and producing a RS (Rerank Score) valuefor the test compound and Acalabrutinib was used as a comparison. This study also conducted bioavailability by predicting the value of $F$ (intestinal human absorption) in the pkCSM program and toxicity studies by predicting LD50 values using the Protox II program. Correlation and regression were performed using the RS, F, and LD50 values that we obtained on the physicochemical properties of the test compound using the IBM SPSS version 24 program. The best equation is obtained as follows: (1) $F=0.851$ Es Taft $-6.116 \sigma-1.969 \pi^{2}+3.620 \pi+90.809$; (2) $R S=$ 4.376 Es Taft - 88.802; (3) $L D 50=672.518$ CMR - 669.385 ClogP - 813.806. From the results of the best equation is obtained that the activity is influenced by the parameters of steric physicochemical properties (Es Taft).
\end{abstract}

Keywords: 1-benzyl-3-benzoylurea, code pdb:5fbn, in-silico, non-hodgkin lymphoma

\begin{abstract}
Abstrak-Pada penelitian ini dilakukan rancangan obat baru antikanker Limfoma non-Hodgkin, dengan pendekatan penambatan molekul dari senyawa induk 1-benzil-3-benzoilurea dan analognya sebagai senyawa antikanker.Tujuan penelitian ini untuk mendapatkan persamaan hubungan struktur aktivitas (HKSA) terbaik. Uji aktivitas in-silico dilakukan terhadap senyawa baru 1benzil-3-benzoilurea dan analognya terhadap reseptor Bruton Tyrosine Kinase (BTK) kode PDB 5FBN dengan menggunakkan program Molegro Virtual Docker 5.5 dan menghasilkan nilai RS (Rerank Score) untuk senyawa uji dan Acalabrutinib digunakan sebagai pembanding. Penelitian ini juga dilakukan studi bioavaibilitas dengan memprediksi nilai F (intestinal human absorbtion) pada program pkCSM dan studi toksisitas dengan memprediksi nilai LD50 menggunakan program Protox II. Korelasi dan regresi dilakukan menggunakan nilai RS, F dan LD50 yang telah diperoleh terhadap parameter sifat fisikokimia senyawa uji menggunakan program IBM SPSS versi 24. Persamaan terbaik yang diperoleh sebagai berikut: (1) $F=-1.969 \pi^{2}+0.851 \mathrm{Es}$ Taft $-6.116 \sigma+3.620 \pi$ +90.809 (2) RS $=4.376$ Es Taft -88.802 (3) LD50 $=672.518$ CMR - 669.385 ClogP - 813.806. Dari hasil persamaan terbaik tersebut diperoleh bahwa aktivitas dipengaruhi oleh parameter sifat fisikokimia sterik (Es Taft).
\end{abstract}

Kata kunci: 1-benzil-3-benzoilurea, in-silico, kode pdb: 5fbn, limfoma non-hodgkin

\section{PENDAHULUAN}

Kanker Limfoma merupakan istilah untuk kanker yang dimulai dalam sel-sel getah bening. Ada dua jenis utama kanker limfoma, yaitu limfoma Hodgkin dan limfoma non-Hodgkin (LNH) (American Cancer Society, 2017). Penderita kanker limfoma 90\% merupakan penderita limfoma non-Hodgkin, dan sisanya $10 \%$ adalah limfoma Hodgkin.Sel-B dan sel-T yang bermutasi pada sistem limfatik menjadi penyebab terjadinya Limfoma non-Hodgkin (Shankland, Amitage, \& Hancock, 2012).

Menurut data dari Globocan (2018) International Agency for Research on Cancer (IARC) di Indonesia untuk kanker secara umum diperkirakan sekitar 348.809 kasus baru dan untuk mortalitas diperkirakan sekitar 207.210. Limfoma non-hodgkin berada pada urutan ketujuh dengan presentase $4.1 \%$ atau sekitar 14.164 untuk kasus baru, dan untuk mortalitas limfoma non-hodgkin berada pada urutan kesembilan dengan presentase $3.7 \%$ atau sekitar 7.565. Dari data tersebut kanker limfoma non- hodgkin dapat terjadi akibat beberapa faktorfaktor umum yaitu: usia, genetik, sistem kekebalan tubuh yang melemah, jenis kelamin dan paparan zat kimia beracun (Kemenkes RI, 2015). 
Pengobatan untuk kanker saat ini yang paling umum adalah kemoterapi, pembedahan, target terapi, dan radioterapi (Arruebo, et al., 2011). Kemoterapi memiliki beberapa kekurangan dan efek samping yang serius seperti depresi sum-sum tulang belakang, neurotoksisitas, mukositis dan reaksi alergi (Anwar et al., 2013). Obat-obat kemoterapi secara klinis digunakan untuk membunuh sel tumor dengan menghambat mekanisme pembelahan sel tumor. Tetapi obat antikanker tidak spesifik membunuh sel kanker saja, menjadikan obat tersebut bersifat toksik bagi semua sel yang sedang membelah, termasuk sel normal (KodaKimble et al., 2008). Oleh karena itu perlu untuk menemukan obat baru antikanker yang spesisfik yang dapat membunuh sel kanker saja.Target terapi mejadi salah satu pilihan dalam dunia pengobatan, karena jenis pengobatan ini menggunakan obat atau zat lain untuk mengindentifikasi dan menyerang sel kanker secara selektif tanpa merusak sel normal. Terapi monoklonal, terapi inhibitor proteasome, dan terapi inhibitor kinase merupakan jenis terapi bertarget yang digunakan untuk mengobati kanker limfoma non-Hodgkin pada orang dewasa (National Cancer Institute, 2019).

Pengembangan obat-obat termasuk obat antikanker membutuhkan waktu yang lama dan biaya yang sangat mahal, Sehingga banyak dikembangkan penelitian-penelitian baru yang berbasis komputasi. Metode-metode seperti CADD (computer-aided drug design) dan CAMD (computer-aided molecular design) sekarang banyak digunakan dalam merancang, menemukan dan melakukan optimasi molekul bioaktif sebagai calon obat yang menjanjikan (Siswandono, 2016). Dalam metode CADD terdapat dua pendekatan, yaitu Structure-Based Drug Design (SBDD) dan Ligand-Based Drug Design (LBDD) (Suhud, 2015). Pendekatan SBDD dan LBDD telah diterapkan sebagai alat penemuan obat yang berharga, baik di dunia akademis dan industri. Molecular docking merupakan metode komputasi yang berbasis ligan, metode ini bertujuan untuk meniru interaksi antara ligan dengan protein (Motiejunas et al., 2006). Molekular docking menjadi salah satu metode yang sering digunakan dalam LBDD karena kemampuannya untuk memprediksi, dengan tingkat keakuratan yang besar danmenghemat biaya serta waktu yang digunakan (Ferreira et al., 2015).

Acalabrutinib (Calquence) adalah obat yang telah disetujui oleh FDA (Food and Drug Administration) dan termasuk obat terapi inhibitor kinase untuk pengobatan leukemia limfositik kronis, limfoma limfositik kecil dan pada pasien dewasa denganpenyakit Mantle cell limfoma (MCL) (Astor, 2019). Acalabrutinib merupakan inhibitor molekul kecil yang tersedia dari Bruton Tyrosine Kinase (BTK) yang merupakan bagian penting dalam jalur pensinyalan reseptor sel-B dan digunakan dalam terapi keganasan sel-B. Penghambatan dalam jalur ini mencegah aktivasi sel-B, mencegah diferensiasi, dan poliferasi (National Institutes of Health, 2019). Reseptor BTK bertindak sebagai penyedia tempat untuk menyatukan beragam protein pensinyalan dan terlibat dalam jalur pensinyalan sitokin (Drugbank, 2016), BTK terutama bekerja pada sel $b$ dan juga terlibat dalam jalur pensinyalan sel $b$ dan memiliki peran penting dalam fisiologis dan proliferasi limfosit b yang ganas (Zhang \& Qiu, 2019).

Pada penelitian ini akan diuji senyawa 1-benzil-3-benzoilurea dan senyawa analognya sebagai calon senyawa antikanker melalui hambatan reseptor BTK. Senyawa 1-benzil-3benzoilurea diperoleh dengan memodifikasi senyawa induk dengan memasukkan gugus bersifat lipofilik seperti gugus aril dan alkil dan penambahan subtituen yang mengandung atom elektronegatif seperti gugus nitro dan halogen untuk meningkatkan sifat elektroniknya. Gugus benzilurea berperan sebagai farmakofor untuk dikembangkan menjadi senyawa antikanker yang lebih poten, sehingga pada penelitian ini gugus benzoil di modifikasi melalui pendekatan lipofilik, elektronik dan sterik sebagai parameter sifat fisikokimia. Pada penelitian ini dipilih 20 substituen dengan penempatan sebagai berikut: (2-kloro, 3- kloro, 4-kloro, 2,4-dikloro, 3,4dikloro, 4-klorometil, 3- klorometil, 4-bromometil, 4-bromo, 4-propil, 3-triflourometil, 2triflourometil, 4-etil, 3- etil, 4-metil, 4-t-butil, 4-fluoro, 4-metoksi, dan 4-nitro) (Suhud, 2017). 
Penambatan (docking) akan dilakukan pada senyawa induk 1-benzil-3- benzoilurea dan senyawa analognya dengan reseptor Bruton Tyrosine Kinase, dengan kode PDB (5FBN) dan ligan 4-[8-azanyl-3-[(3 \{R\})-1-(3-methyloxetan-3- yl)carbonylpiperidin-3-yl]imidazo[1,5a]pyrazin-1-yl]- $\sim$ N $\}$ [4(trifluoromethyl) pyridin-2- yl]benzamide. Kode PDB 5FBN dipilih berdasarkan kemiripan struktur farmakofor obat pembanding Acalabrutinib yaitu pada gugus benzamida.

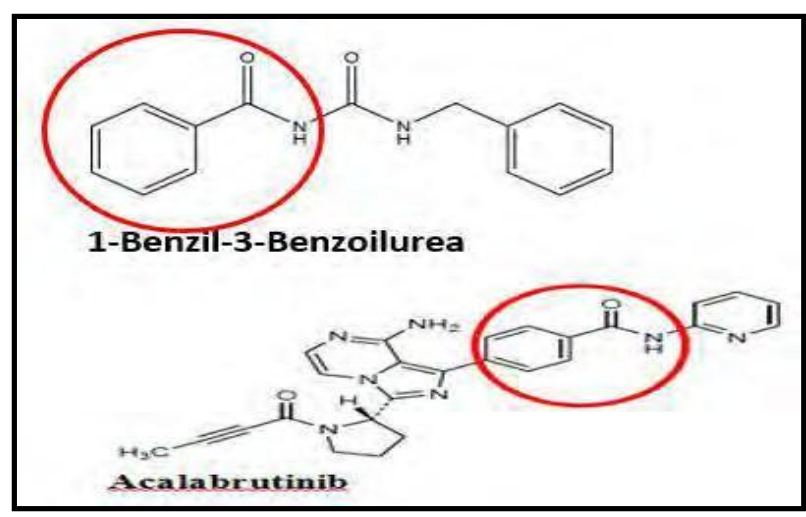

Gambar 1. Struktur acalabrutinib yang memiliki kesamaan dengan senyawa uji (Suhud, 2015 ; Drugbank, 2016).

\section{METODE}

Pada penelitian ini dilakukan studi Hubungan Kuantitatif Struktur-Aktivitas (HKSA) secara in-silico, dalam upaya pengembangan senyawa antikanker baru untuk terapi kanker limfoma non-Hodgkin. Studi HKSA merupakan upaya dalam desain obat, untuk membuat persamaan hubungan struktur dengan aktivitas biologis dari suatu senyawa.

Pada penelitian ini diperlukan makromolekul protein dari reseptor. Reseptor yang dipilih pada penelitian ini yaitu reseptor Bruton Tyrosine Kinase (BTK) dengan kode makromolekul protein (PDB) 5FBN, yang dapat diunduh pada website Protein Data Bank. Gambar struktur 2D dari senyawa uji 1-benzil-3benzoilurea dan analognya dan senyawa pembanding Acalabrutinib, yang dapat dibuat dengan menggunakan program Chemdraw ultra 12. Gambar struktur 3D dari senyawa uji dapat dibuat dengan program Chembio3D Ultra 12. Sifat fisikokimia senyawa diperoleh dengan menggunakan programChemdraw, Chembio3D dan tabel Hansch. Molecular docking dilakukan dengan menggunakan program Molegro Virtual Docker 5.5, Prediksi ADME dilakukan dengan program web online pkCSM dan prediksi toksisitas dilakukan dengan menggunakan program web online Protox II. Semua data yang diperoleh diolah dengan menggunakan program statistika IBM SPSS versi 24, untuk mengetahui hubungan dan membuat persamaan HKSA.

Parameter yang diamati pada penelitian ini yaitu parameter sifat fisikokimia meliputi (1) Parameter Lipofilik (ClogP, tetapan $\pi$ Hansch), (2) Parameter Elektronik (Etot, dan tetapan $\sigma$ Hammet), (3) Parameter Sterik (Es taft dan CMR). Parameter Bioavailabilitas yaitu nilai Intestinal absorption (F), parameter Aktivitas yaitu nilai rerank score dan RMSD, parameter Toksisitas yaitu nilai LD50.

Langkah pertama, mengunduh file makromolekul reseptor BTK dengan kode 5FBN. Dilanjutkan dengan membuat struktur 2D dan 3D dari senyawa uji 1-benzil-3- benzoilurea dan analognya menggunakan program berturut-turut Chemdraw ultra 12 dan Chembio3D ultra 12. Struktur 3D dilakukan penstabilan terlebih dahulu sebelum digunakan untuk molecular docking dengan fitur MM2 minimization pada program Chembio3D ultra 13. Struktur 3D yang sudah stabil digunakan untuk molecular docking dengan menggunakan program Molegro Virtual Docker 5.5 untuk memperoleh nilai rerank score, RMSD dan melihat ikatan obat dengan reseptor. Prediksi ADME dilakukan dengan menggunakan program pkCSM dengan menginput 
file 3D senyawa uji yang sudah dikonversi ke bentuk SMILE file, hasil yang diperoleh yaitu prediksi nilai intestinal human absorbtion (F). Prediksi toksisitas dilakukan dengan menggunakan program Protox II dengan menginput file 2D dari senyawa uji dalam bentuk txt file, hasil yang diperoleh yaitu prediksi nilai LD50. Tahap terakhir yang dilakukan yaitu membuat persamaan HKSA untuk melihat hubungan antara parameter sifat fisikokimia dengan parameter bioavailabilitas, aktivitas dan toksisitas, dengan menggunakan program statistika IBM SPSS versi 24.

HASIL

\section{Parameter Bioavaibilitas (F)}

Pada uji prediksi bioavailabilitas dengan menggunakan program web online pkCSM dapatkan hasil senyawa pembanding memiliki nilai $F$ (bioavailabilitas) lebih tinggidari senyawa uji. Senyawa uji yang memiliki nilai $F$ (bioavailabilitas) terbaik yaitu senyawa 1-Benzil-3-(4OCH3-benzoil)urea dengan nilai 93,277\% sedangkan senyawa pembanding yang diperoleh dari Acalabrutinib dengan nilai F (bioavailabilitas) 94,184 \%. Hasil uji dapat dilihat pada Tabel 1.

\section{Parameter Aktivitas (RS)}

Pada uji aktivitas dapatkan hasil prediksi nilai Rerank Score paling baik dari semua senyawa uji lain, yaitu senyawa 1-Benzil-3-(3-CF3-benzoil)urea dengan nilai Rerank Score $103.9030 \mathrm{kkal} / \mathrm{mol}$, lebih besar dibandingkan dengan senyawa pembanding yaitu Acalabrutinib dengan nilai Rerank Score $-154.1513 \mathrm{kkal} / \mathrm{mol}$ dengan nilai RMSD 0,5552 A. Rendahnya nilai Rerank Score Acalabrutinib menunjukkan senyawa obat pembanding ini memiliki aktivitas yang lebih baik dibandingkan senyawa uji 1- Benzil-3-Benzoilurea dan analognya.. Ini menggambarkan semakin rendah nilai Rerank Score maka semakin rendah juga energi yang dibutuhkan untuk berikatan, sehingga ikatan yang terbentuk semakin stabil. Hasil uji dapat dilihat pada Tabel 2.

\section{Tabel 1}

Hasil Prediksi Nilai Bioavailabilitas (F) Dari Senyawa 1-Benzil-3-Benzoilurea dan Analognya

\begin{tabular}{llll}
\hline Nama Senyawa & $\mathbf{F ~ ( \% )}$ & Nama Senyawa & F (\%) \\
\hline 1-Benzil-3-benzoilurea & 92,029 & 1-Benzil-3-(4-C3H7-benzoil)urea & 91,355 \\
1-Benzil-3-(2-Cl-benzoil)urea & 90,368 & 1-Benzil-3-(4-t-C4H9-benzoil)urea & 90,533 \\
1-Benzil-3-(3-Cl-benzoil)urea & 91,239 & 1-Benzil-3-(4-F-benzoil)urea & 91,783 \\
1-Benzil-3-(4-Cl-benzoil)urea & 90,827 & 1-Benzil-3-(2-CF3-benzoil)urea & 88,755 \\
1-Benzil-3-(2,4-di-Cl-benzoil)urea & 89,166 & 1-Benzil-3-(3-CF3-benzoil)urea & 89,906 \\
1-Benzil-3-(3,4-di-Cl-benzoil)urea & 90,496 & 1-Benzil-3-(4-CH2Br-benzoil)urea & 90,834 \\
1-Benzil-3-(4-CH2Cl-benzoil)urea & 91,009 & 1-Benzil-3-(4-OCH3-benzoil)urea & 93,277 \\
1-Benzil-3-(3-CH2Cl-benzoil)urea & 90,890 & 1-Benzil-3-(4-NO2-benzoil)urea & 82,229 \\
1-Benzil-3-(4-CH3-benzoil)urea & 92,285 & 1-Benzil-3-(4-Br-benzoil)urea & 90,760 \\
1-Benzil-3-(4-C2H5-benzoil)urea & 92,083 & Acalabrutinib & 94,184 \\
1-Benzil-3-(3-C2H5-benzoil)urea & 91,964 & & \\
\hline
\end{tabular}




\section{Tabel 2}

Hasil Uji Aktivitas dari Senyawa 1-benzil-3-benzoilurea dan Analognya

\begin{tabular}{|c|c|c|c|c|c|}
\hline \multirow[b]{2}{*}{ No. } & \multirow[b]{2}{*}{ Nama Senyawa } & \multicolumn{4}{|c|}{ Rerank Score } \\
\hline & & $\mathbf{I}$ & II & III & Rata-rata \\
\hline 1 & 1-Benzil-3-benzoilurea & -87.4983 & -90.7377 & -91.1108 & -89.7823 \\
\hline 2 & 1-Benzil-3-(2-Cl-benzoil)urea & -78.7147 & -83.1877 & -81.9761 & -81.2928 \\
\hline 3 & 1-Benzil-3-(3-Cl-benzoil)urea & -91.1085 & -86.7141 & -86.4327 & -88.0851 \\
\hline 4 & 1-Benzil-3-(4-Cl-benzoil)urea & -83.7347 & -83.1124 & -85.0553 & -83.9675 \\
\hline 5 & 1-Benzil-3-(2,4-di-Cl-benzoil)urea & -74.8406 & -78.913 & -80.8924 & -78.2153 \\
\hline 6 & 1-Benzil-3-(3,4-di-Cl-benzoil)urea & -86.1932 & -90.6174 & -87.6998 & -88.1710 \\
\hline 7 & 1-Benzil-3-(4- $\mathrm{CH}_{2} \mathrm{Cl}$-benzoil)urea & -85.6967 & -90.1372 & -82.0237 & -85.9525 \\
\hline 8 & 1-Benzil-3-(3- $\mathrm{CH}_{2} \mathrm{Cl}$-benzoil)urea & -90.6750 & -94.6627 & -95.5919 & -93.6432 \\
\hline 9 & 1-Benzil-3-(4- $\mathrm{CH}_{3}$-benzoil)urea & -84.2295 & -78.5429 & -85.5080 & -82.7601 \\
\hline 10 & 1-Benzil-3-(4- $\mathrm{C}_{2} \mathrm{H}_{5}$-benzoil)urea & -89.7963 & -88.3818 & -91.0948 & -89.7576 \\
\hline 11 & 1-Benzil-3-(3- $\mathrm{C}_{2} \mathrm{H}_{5}$-benzoil)urea & -98.3457 & -93.3203 & -95.7457 & -95.8039 \\
\hline 12 & 1-Benzil-3-(4- $\mathrm{C}_{3} \mathrm{H}_{7}$-benzoil)urea & -88.7189 & -99.4989 & -95.3863 & -94.5347 \\
\hline 13 & 1-Benzil-3-(4-t- $\mathrm{C}_{4} \mathrm{H}_{9}$-benzoil)urea & -88.5737 & -97.4096 & -100.821 & -95.6014 \\
\hline 14 & 1-Benzil-3-(4-F-benzoil)urea & -88.3184 & -91.2561 & -92.4993 & -90.6913 \\
\hline 15 & 1-Benzil-3-(2-CF 3 -benzoil)urea & -89.1847 & -97.0757 & -86.5028 & -90.9211 \\
\hline 16 & 1-Benzil-3-(3-CF 3 -benzoil)urea & -102.965 & -106.091 & -102.653 & -103.9030 \\
\hline 17 & 1-Benzil-3-(4- $\mathrm{CH}_{2} \mathrm{Br}$-benzoil)urea & -93.6182 & -90.8014 & -81.8780 & -88.7659 \\
\hline 18 & 1-Benzil-3-(4-OCH ${ }_{3}$-benzoil)urea & -89.6315 & -95.7558 & -95.0823 & -93.4899 \\
\hline 19 & 1-Benzil-3-(4-NO ${ }_{2}$-benzoil)urea & -94.075 & -93.5481 & -89.8186 & -92.4806 \\
\hline 20 & 1-Benzil-3-(4-Br-benzoil)urea & -86.3085 & -86.8358 & -88.0009 & -87.0484 \\
\hline 21 & Acalabrutinib & -154.0640 & -154.1470 & -154.2430 & -154.1513 \\
\hline
\end{tabular}

Parameter Toksisitas (LD50)

Pada uji LD50 (toksisitas) dapatkan hasil uji toksisitas (nilai LD50) yang tertinggi yaitu senyawa 1-Benzil-3-(2-Cl-benzoil)urea,1-Benzil-3-(3-CH2Cl-benzoil)urea, 1-Benzil-3- (2-CF3benzoil)urea dengan nilai LD50 $3000 \mathrm{mg}$ dan toksisitas kelas 5. Lebih besar apabila dibandingkan dengan senyawa pembanding yaitu Acalabrutinib dengan nilai LD50 $135 \mathrm{mg}$ dan toksisitas kelas 3 . Nilai dan kelas toksisitas tersebut menandakan bahwa senyawa uji mungkin berbahaya jika tertelan. Hasil uji dapat dilihat pada Tabel 3. 


\section{Tabel 3}

Hasil Uji Toksisitas Dari Senyawa 1-Benzil-3-Benzoilurea dan Analogny

\begin{tabular}{|c|c|c|c|}
\hline No & Nama Senyawa & $\begin{array}{c}\text { LD50 } \\
(\mathrm{mg} / \mathrm{kg})\end{array}$ & $\begin{array}{c}\text { Kelas } \\
\text { Toksisitas }\end{array}$ \\
\hline 1 & 1-Benzil-3-benzoilurea & 1950 & 4 \\
\hline 2 & 1-Benzil-3-(2-Cl-benzoil)urea & 3000 & 5 \\
\hline 3 & 1-Benzil-3-(3-Cl-benzoil)urea & 2000 & 4 \\
\hline 4 & 1-Benzil-3-(4-Cl-benzoil)urea & 2000 & 4 \\
\hline 5 & 1-Benzil-3-(2,4-di-Cl-benzoil)urea & 2000 & 4 \\
\hline 6 & 1-Benzil-3-(3,4-di-Cl-benzoil)urea & 2000 & 4 \\
\hline 7 & 1-Benzil-3-(4- $\mathrm{CH}_{2} \mathrm{Cl}$-benzoil)urea & 1950 & 4 \\
\hline 8 & 1-Benzil-3-(3- $\mathrm{CH}_{2} \mathrm{Cl}$-benzoil)urea & 3000 & 5 \\
\hline 9 & 1-Benzil-3-(4- $\mathrm{CH}_{3}$-benzoil)urea & 818 & 4 \\
\hline 10 & 1-Benzil-3-(4- $\mathrm{C}_{2} \mathrm{H}_{5}$-benzoil)urea & 2000 & 4 \\
\hline 11 & 1-Benzil-3-(3- $\mathrm{C}_{2} \mathrm{H}_{5}$-benzoil)urea & 2000 & 4 \\
\hline 12 & 1-Benzil-3-(4- $\mathrm{C}_{3} \mathrm{H}_{7}$-benzoil)urea & 2000 & 4 \\
\hline 13 & 1-Benzil-3-(4- $t-\mathrm{C}_{4} \mathrm{H}_{9}$-benzoil)urea & 2000 & 4 \\
\hline 14 & 1-Benzil-3-(4-F-benzoil)urea & 2000 & 4 \\
\hline 15 & 1-Benzil-3-(2- $\mathrm{CF}_{3}$-benzoil)urea & 3000 & 5 \\
\hline 16 & 1-Benzil-3-(3-CF 3 -benzoil)urea & 2000 & 4 \\
\hline 17 & 1-Benzil-3-(4- $\mathrm{CH}_{2} \mathrm{Br}$-benzoil)urea & 1950 & 4 \\
\hline 18 & 1-Benzil-3-(4-OCH- -benzoil)urea & 2000 & 4 \\
\hline 19 & 1-Benzil-3-(4-NO ${ }_{2}$-benzoil)urea & 2850 & 5 \\
\hline 20 & 1-Benzil-3-(4-Br-benzoil)urea & 2000 & 4 \\
\hline 21 & Acalabrutinib & 135 & 3 \\
\hline
\end{tabular}

\section{Analisis Hukum 5 Lipinski}

Analisis terhadap Hukum Lima Lipinski didapat hasil bahwa semua senyawa memenuhi syarat, sehingga dapat disimpulkan bahwa senyawa - senyawa tersebut diprediksi memiliki kemampuan untuk menembus membran yang baik. Dan dapat juga diprediksi bahwa senyawa - senyawa tersebut memiliki absorbsi yang baik. Hasil dapat dilihat pada Tabel 4. 
Tabel 4

Analisis Hukum Lima Lipinski Dari Sifat Fisikokimia Senyawa 1-Benzil-3-Benzoilurea Dan Analognya

\begin{tabular}{|c|c|c|c|c|c|}
\hline No & $\begin{array}{l}\text { Nama Senyawa } \\
\text { Ketentuan }\end{array}$ & $\begin{array}{l}\text { BM } \\
<500\end{array}$ & $\begin{array}{l}\log P \\
<5\end{array}$ & $\begin{array}{l}\text { Ikatan H } \\
\text { Donor } \\
<5\end{array}$ & $\begin{array}{c}\text { Ikatan H } \\
\text { Aseptor } \\
<10\end{array}$ \\
\hline 1 & 1-Benzil-3-benzoilurea & 254,289 & 2,3262 & 2 & 2 \\
\hline 2 & 1-Benzil-3-(2-Cl-benzoil)urea & 288,734 & 2,9796 & 2 & 2 \\
\hline 3 & 1-Benzil-3-(3-Cl-benzoil)urea & 288,734 & 2,9796 & 2 & 2 \\
\hline 4 & 1-Benzil-3-(4-Cl-benzoil)urea & 288,734 & 2,9796 & 2 & 2 \\
\hline 5 & 1-Benzil-3-(2,4-di-Cl-benzoil)urea & 323,179 & 3,633 & 2 & 2 \\
\hline 6 & 1-Benzil-3-(3,4-di-Cl-benzoil)urea & 323,179 & 3,633 & 2 & 2 \\
\hline 7 & 1-Benzil-3-(4- $\mathrm{CH}_{2} \mathrm{Cl}$-benzoil)urea & 302,761 & 3,065 & 2 & 2 \\
\hline 8 & 1-Benzil-3-(3- $\mathrm{CH}_{2} \mathrm{Cl}$-benzoil)urea & 302,761 & 3,065 & 2 & 2 \\
\hline 9 & 1-Benzil-3-(4- $\mathrm{CH}_{3}$-benzoil)urea & 268,316 & 2,63462 & 2 & 2 \\
\hline 10 & 1-Benzil-3-(4- $\mathrm{C}_{2} \mathrm{H}_{5}$-benzoil)urea & 282,343 & 2,8886 & 2 & 2 \\
\hline 11 & 1-Benzil-3-(3- $\mathrm{C}_{2} \mathrm{H}_{5}$-benzoil)urea & 282,343 & 2,8886 & 2 & 2 \\
\hline 12 & 1-Benzil-3-(4- $\mathrm{C}_{3} \mathrm{H}_{7}$-benzoil)urea & 296,37 & 3,2787 & 2 & 2 \\
\hline 13 & 1-Benzil-3-(4- $t-\mathrm{C}_{4} \mathrm{H}_{9}$-benzoil)urea & 310,397 & 3,6237 & 2 & 2 \\
\hline 14 & 1-Benzil-3-(4-F-benzoil)urea & 272,279 & 2,4653 & 2 & 2 \\
\hline 15 & 1-Benzil-3-(2-CF - -benzoil)urea & 322,286 & 3,345 & 2 & 2 \\
\hline 16 & 1-Benzil-3-(3-CF - -benzoil)urea & 322,286 & 3,345 & 2 & 2 \\
\hline 17 & 1-Benzil-3-(4- $\mathrm{CH}_{2} \mathrm{Br}$-benzoil)urea & 347,212 & 3,2211 & 2 & 2 \\
\hline 18 & 1-Benzil-3-(4-OCH 3 -benzoil)urea & 284,315 & 2,3348 & 2 & 2 \\
\hline 19 & 1-Benzil-3-(4- $\mathrm{NO}_{2}$-benzoil)urea & 299,286 & 2,2344 & 2 & 2 \\
\hline 20 & 1-Benzil-3-(4-Br-benzoil)urea & 333,185 & 3,0887 & 2 & 2 \\
\hline 21 & Acalabrutinib & 474,26 & 4,077 & 2 & 5 \\
\hline
\end{tabular}

Pada penelitian ini dilakukan pengamatan terhadap ikatan obat dengan reseptor. Hasil pengamatan pada penelitian ini hanya ditemukan ikatan hidrogen yangdapat dilihat pada Tabel 5 dan interaksi sterik yang dapat dilihat pada Tabel 6. Pada penelitian ini tidak ditemukan adanya ikatan elektronik.

\section{Correlation Matrix}

Pada uji korelasi diperoleh hasil sebagai berikut:

1. $\sigma$ Hammet berpengaruh secara signifikan pada $p<0,01$ terhadap bioavailabilitas dengan nilai korelasi Pearson-0,773 dengan signifikansi 0,000dan juga berpengaruh signifikan pada $\mathrm{p}<0,05$ terhadap toksisitas dengan nilai korelasi Pearson0,481 dengan signifikansi 0,032.

2. Es Taff berpengaruh secara signifikan pada $p<0,05$ terhadap bioavailabilitasdengan nilai korelasi Pearson 0.447 dengan signifikansi 0,048 dan Es Taft juga berpengaruh siginifikan pada $\mathrm{p}<0,05$ terhadap aktivitas dengan nilai korelasi Pearson 0,551 dengan signifikansi 0,012 .

Hipotesa diuji dengan menggunakan analisis regresi secara linier. Hasil yang didapat lebih obyektif yaitu berupa persamaan yang lebih mudah dipahami. Regresi yang dilakukan yaitu satu parameter, dua parameter dan tiga parameter variabel bebas sifat fisikokimia dengan variabel tergantung bioavailabilitas, aktivitas dan toksisitas. 


\section{Tabel 5}

Ikatan Hidrogen Antara Asam Amino Dengan Senyawa Acalabrutinib, 1-Benzil-3-Benzoilurea dan Analognya Terhadap Reseptor BTK

\begin{tabular}{|c|c|c|c|c|c|c|}
\hline No & Nama Senyawa & $\begin{array}{l}\text { Ser } \\
538\end{array}$ & $\begin{array}{l}\text { Asp } \\
539\end{array}$ & $\begin{array}{r}\text { Met } \\
477\end{array}$ & $\begin{array}{l}\text { Glu } \\
475\end{array}$ & $\begin{array}{l}\text { Thr } \\
474\end{array}$ \\
\hline 1. & 1-Benzil-3-benzoilurea & $2+$ & - & - & - & + \\
\hline 2. & 1-Benzil-3-(2-Cl-benzoil)urea & - & $2+$ & - & - & - \\
\hline 3. & 1-Benzil-3-(3-Cl-benzoil)urea & - & $2+$ & - & - & - \\
\hline 4. & 1-Benzil-3-(4-Cl-benzoil)urea & + & + & - & - & + \\
\hline 5. & 1-Benzil-3-(2,4-di-Cl-benzoil)urea & + & - & - & - & - \\
\hline 6. & 1-Benzil-3-(3,4-di-Cl-benzoil)urea & + & + & - & - & + \\
\hline 7. & 1-Benzil-3-(4- $\mathrm{CH}_{2} \mathrm{Cl}$-benzoil)urea & + & + & - & - & - \\
\hline 8. & 1-Benzil-3-(3- $\mathrm{CH}_{2} \mathrm{Cl}$-benzoil)urea & + & + & - & - & - \\
\hline 9. & 1-Benzil-3-(4- $\mathrm{CH}_{3}$-benzoil)urea & + & + & - & - & - \\
\hline 10. & 1-Benzil-3-(4- $\mathrm{C}_{2} \mathrm{H}_{5}$-benzoil)urea & + & + & - & - & - \\
\hline 11. & 1-Benzil-3-(3- $\mathrm{C}_{2} \mathrm{H}_{5}$-benzoil)urea & $2+$ & - & - & - & - \\
\hline 12. & 1-Benzil-3-(4- $\mathrm{C}_{3} \mathrm{H}_{7}$-benzoil)urea & - & - & - & - & - \\
\hline 13. & 1-Benzil-3-(4-t- $\mathrm{C}_{4} \mathrm{H}_{9}$-benzoil)urea & + & - & - & - & $2+$ \\
\hline 14. & 1-Benzil-3-(4-F-benzoil)urea & + & + & - & - & - \\
\hline 15. & 1-Benzil-3-(2-CF -benzoil)urea & + & - & - & - & - \\
\hline 16. & 1-Benzil-3-(3-CF 3 -benzoil)urea & + & + & - & - & + \\
\hline 17. & 1-Benzil-3-(4- $\mathrm{CH}_{2} \mathrm{Br}$-benzoil)urea & - & - & - & - & + \\
\hline 18. & 1-Benzil-3-(4-OCH 3 -benzoil)urea & - & + & - & - & + \\
\hline 19. & 1-Benzil-3-(4-NO ${ }_{2}$-benzoil)urea & - & - & + & + & $2+$ \\
\hline 20. & 1-Benzil-3-(4-Br-benzoil)urea & + & + & - & - & + \\
\hline 21. & Acalabrutinib & $2+$ & + & + & + & + \\
\hline
\end{tabular}




\section{Tabel 6}

Interaksi Sterik Antara Asam Amino Dengan Senyawa Acalabrutinib, 1-Benzil-3-Benzoilurea dan Analognya Terhadap Reseptor BTK

\begin{tabular}{|c|c|c|c|c|c|c|c|c|c|}
\hline No & Nama Senyawa & $\begin{array}{l}\text { Ser } \\
538\end{array}$ & $\begin{array}{l}\text { Asp } \\
539\end{array}$ & $\begin{array}{l}\text { Leu } \\
408\end{array}$ & $\begin{array}{l}\text { Leu } \\
460\end{array}$ & $\begin{array}{l}\text { Lys } \\
\mathbf{4 3 0}\end{array}$ & $\begin{array}{c}\text { Met } \\
477\end{array}$ & $\begin{array}{l}\text { Thr } \\
\mathbf{4 7 4}\end{array}$ & $\begin{array}{l}\text { Ala } \\
428\end{array}$ \\
\hline 1 & 1-Benzil-3-benzoilurea & - & - & - & - & - & - & + & - \\
\hline 2 & 1-Benzil-3-(2-Cl-benzoil)urea & + & $2+$ & - & $2+$ & + & - & - & - \\
\hline 3 & 1-Benzil-3-(3-Cl-benzoil)urea & - & - & - & - & $2+$ & - & + & - \\
\hline 4 & 1-Benzil-3-(4-Cl-benzoil)urea & + & - & - & - & - & - & $2+$ & + \\
\hline 5 & 1-Benzil-3-(2,4-di-Cl-benzoil)urea & + & $2+$ & - & - & - & - & + & - \\
\hline 6 & 1-Benzil-3-(3,4-di-Cl-benzoil)urea & + & - & - & - & - & - & - & + \\
\hline 7 & 1-Benzil-3-(4- $\mathrm{CH}_{2} \mathrm{Cl}$-benzoil)urea & - & - & - & - & - & - & + & - \\
\hline 8 & 1-Benzil-3-(3- $\mathrm{CH}_{2} \mathrm{Cl}$-benzoil)urea & - & - & - & - & - & - & + & + \\
\hline 9 & 1-Benzil-3-(4- $\mathrm{CH}_{3}$-benzoil)urea & - & - & - & - & - & - & + & - \\
\hline 10 & 1-Benzil-3-(4- $\mathrm{C}_{2} \mathrm{H}_{5}$-benzoil)urea & - & - & - & - & + & + & + & + \\
\hline 11 & 1-Benzil-3-(3- $\mathrm{C}_{2} \mathrm{H}_{5}$-benzoil)urea & + & - & - & - & - & - & - & - \\
\hline 12 & 1-Benzil-3-(4- $\mathrm{C}_{3} \mathrm{H}_{7}$-benzoil)urea & - & - & - & - & - & $2+$ & + & - \\
\hline 13 & 1-Benzil-3-(4- $t-\mathrm{C}_{4} \mathrm{H}_{9}$-benzoil)urea & + & - & - & - & - & - & + & - \\
\hline 14 & 1-Benzil-3-(4-F-benzoil)urea & + & + & - & + & + & - & - & + \\
\hline 15 & 1-Benzil-3-(2-CF - -benzoil)urea & + & - & - & $2+$ & + & - & + & + \\
\hline 16 & 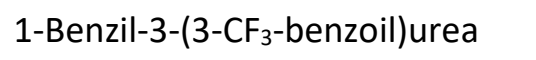 & + & - & - & - & - & + & - & - \\
\hline 17 & 1-Benzil-3-(4- $\mathrm{CH}_{2} \mathrm{Br}$-benzoil)urea & - & - & - & - & - & + & + & + \\
\hline 18 & 1-Benzil-3-(4-OCH -benzoil)urea & - & - & - & - & - & - & - & - \\
\hline 19 & 1-Benzil-3-(4- $\mathrm{NO}_{2}$-benzoil)urea & - & - & - & - & - & - & - & - \\
\hline 20 & 1-Benzil-3-(4-Br-benzoil)urea & + & - & - & - & - & - & $2+$ & - \\
\hline 21 & Acalabrutinib & + & - & $2+$ & - & - & - & - & - \\
\hline
\end{tabular}

\section{Analisis Regresi Sifat Fisikokimia Terhadap Bioavaibilitas}

Persamaan HKSA dari satu parameter yang paling baik terhadap bioavailabilitas diperoleh persamaan linier sebagai berikut: $y=-5,999 \sigma+91,558$ dengan nilai $r=0,773$; $S E=$ 1,$457 ; \mathrm{F}=26,734 ; \mathrm{Sig}=0,000$ dan $\mathrm{n}=20$.

Persamaan dari dua parameter yang paling baik terhadap bioavailabilitas diperoleh persamaan nonlinier sebagai berikut: $y=-2,655 \pi^{2}+4,367 \pi-6,551 \sigma+90,749$ dengan nilai $r$ $=0,906 ; \mathrm{SE}=1,033 ; \mathrm{F}=24,347 ; \mathrm{Sig}=0,000$ dan $n=20$.

Persamaan dari tiga parameter yang paling baik terhadap bioavailabilitas diperoleh persamaan nonlinier sebagai berikut: $y=-1,969 \pi^{2}+3,620 \pi-6,116 \sigma+0,851$ Es Taft $+90,809$ dengan nilai $r=0,936 ; S E=0,883 ; F=26,703 ;$ Sig $=0,000$ dan $n=20$.

\section{Analisis Regresi Sifat Fisikokimia Terhadap Aktivitas (RS)}

Berdasarkan hasil yang diperoleh persamaan HKSA dari satu parameter yang paling baik terhadap Aktivitas diperoleh persamaan linier sebagai berikut: $y=4.376$ Es Taft -88.802 dengan nilai $r=0.551 ; \mathrm{SE}=5.00450 ; \mathrm{F}=7.851 ; \mathrm{Sig}=0.012$ dan $\mathrm{n}=20$.

Pada persamaan dari dua parameter yang paling baik terhadap Aktivitas diperoleh persamaan nonlinier sebagai berikut: $y=4.489$ Es Taft $+3.443 \sigma-89.334$ dengan nilai $r=0.577$; $\mathrm{SE}=5.04245 ; \mathrm{F}=4.232 ;$ Sig 0.032 dan $\mathrm{n}=20$.

Pada persamaan dari tiga parameter tidak diperoleh hasil yang signifikan. 


\section{Analisis Regresi Sifat Fisikokimia Terhadap Toksisitas (LD50)}

Persamaan HKSA pada satu parameter yang paling baik terhadap Toksisitas diperoleh persamaan linier sebagai berikut: $y=839,932 \sigma+1990,251$ dengan nilai $r=0,481$; $S E=$ 453,248; $F=5,414 ;$ Sig = 0,032; $n=20$.

Persamaan dari dua parameter yang paling baik terhadap Toksisitas diperoleh persamaan linier sebagai berikut: $y=-669,385 \operatorname{Clog} P-672,518 C M R-813,806$ dengan nilai $r=$ 0,$547 ; \mathrm{SE}=445,280 ; \mathrm{F}=3,630 ; \mathrm{Sig}=0,049 ; \mathrm{n}=20$.

Pada persamaan dari tiga parameter tidak diperoleh hasil yang signifikan.

\section{BAHASAN}

Prediksi data bioavailabilitas diperoleh melalui program web onlinepkCSMPharmakokinetics, dengan cara menginput data SMILE dan dipilih opsi prediksi admet, kemudian program akan melakukan analisa, dan diperoleh data berupa prediksi nilai intestinal absorption (Human). Nilai bioavaibilitas merupakan presentase dan kecepatan dari zat aktif senyawa obat untuk mencapai sirkulasi sistemik dalam bentuk aktif. Nilai dari intestinal absorption (Human) dianggap sebagai nilai bioavaibilitas. Senyawa obat dikatakan memiliki bioavaibilitas yang baik jika nilai dari senyawa obat diatas 70\%(BPOM, 2005). Pada penelitian ini diperoleh hasil senyawa pembanding lebih tinggi dari senyawa uji. Senyawa uji yang memiliki nilai $\mathrm{F}$ (bioavaibilitas) terbaik yaitu senyawa 1- Benzil-3-(4-OCH nilai 93,277 \%, sedangkan senyawa uji yaitu Acalabrutinib memiliki nilai F (bioavaibilitas) 94.184 $\%$.

Prediksi data aktivitas diperoleh dengan melakukan molecular docking pada program Molegro Virtual Docker versi 5.5. Parameter yang di dapatkan dari molecular docking ini adalah Rerank Score, RMSD, Hbond, dan Muldock Score. Rerank Score (RS) menggambarkan prediksi aktivitas senyawa obat yang merupakan parameter penting dalam molecular docking ini, rerank score merupakan nilai dari hasil pengurutan kembali energi kimia seperti muldock score dan energi sterik lainnya yang telah diminimalkan, dan mempertimbangkan faktor lain seperti RMSD (Root Mean Square Deviation). Pada penelitian ini diperoleh hasil nilai Rerank Score senyawa uji memiliki nilai lebih tinggi dibandingkan dengan senyawa pembanding yaitu Acalabrutinib. Semakin rendah nilai rerank score menunjukkan semakin rendah energi yang dibutuhkan untuk berikatan, sehingga ikatan yang terbentuk semakin stabil. Prediksi nilai Rerank Score terendah dari senyawa uji yaitu 1-Benzil-3-(3- $\mathrm{CF}_{3}$-benzoil)urea dengan nilai Rerank Score -103,9030 kkal/mol, sedangkan senyawa pembanding yaitu Acalabrutinib dengan nilai Rerank Score -154,1513 kkal/moldengan nilai RMSD 0,5552 A. Rendahnya nilai Rerank Score Acalabrutinib menunjukkan senyawa obat pembanding ini memiliki aktivitas yang lebih baik dibandingkan senyawa uji 1-Benzil-3-Benzoilurea dan analognya.

Prediksi data toksisitas diperoleh melalui program webonline Protox II, data yang diperoleh berupa nilai LD50 dan kelas toksisitas dari senyawa tersebut. Nilai LD50 merupakan median dosis atau jumlah dosis yang mampu mematikan $50 \%$ dari subjek uji setelah terpapar senyawa yang diujikan dan kelas toksisitas merupakan klasifikasi palabelan bahan kimia yang telah diselaraskan dengan nilai LD50 (Banerjee P., 2019) dengan klasifikasi oleh webonline Protox II sebagai berikut:

- Kelas 1 : fatal jika tertelan (LD50 5 )

- Kelas 2 : fatal jika tertelan $(5<\mathrm{LD} 50 \leq 50)$

- Kelas 3 : beracun jika tertelan $(50<$ LD50 $\leq 300)$

- Kelas 4 : berbahaya jika tertelan $(300<$ LD50 $\leq 2000)$

- Kelas 5 : mungkin berbahaya bila tertelan $(2000<$ LD50 $\leq 5000)$

- Kelas 6 : tidak beracun (LD50>5000) 
Hasil prediksi toksisitas dapat dilihat pada Tabel 4.5, dari penelitian ini diperoleh hasil nilai LD50 (toksisitas) yang terbaik adalah senyawa 1-Benzil-3-(2-Cl- benzoil)urea,1-Benzil-3-(3$\mathrm{CH}_{2} \mathrm{Cl}$-benzoil)urea, 1-Benzil-3-(2-- $\mathrm{CF}_{3}$-benzoil)ureadengan nilai LD50 $3000 \mathrm{mg}$ dan toksisitas kelas 5. Sedangkan nilai LD50 terendah pada senyawa uji yaitu $818 \mathrm{mg} / \mathrm{kg}$ dengan toksisitas kelas 4 pada senyawa 1-Benzil-3-(4- $\mathrm{CH}_{3}$-benzoil)urea. Senyawa pembanding yaitu Acalabrutinibmemiliki nilai LD50132 mg/kg dan toksisitas kelas 3. Oleh karena itu, dapat disimpulkan seluruh senyawa uji yaitu 1-Benzil-3-Benzoilurea dan analognya mempunyai nilai LD50 dan kelas toksisitas lebih besar daripada senyawapembanding Acalabrutinib.

Berdasarkan analisis terhadap Hukum Lima Lipinski, hasil semua senyawa memenuhi syarat yang bisa disimpulkan. Bahwa senyawa-senyawa tersebut diprediksi mempunyai kemampuan menembus membran yang baik serta diprediksi senyawa- senyawa tersebut memiliki absorbsi yang baik. Berikut syarat aturan dari lima Lipinski

1. Massa molekul kurang dari 500

2. Nilai terhitung dari log $P$ kurang dari 5

3. Kurang dari sepuluh akseptor ikatan hidrogen, misal : -O-,-N- dll

4. Kurang dari lima kelompok donor ikatan hidrogen, misal : $\mathrm{NH}, \mathrm{OH}$ dll

5. Mempunyai ikatan $\mathrm{H}$ aseptor yang dinyatakan dengan jumlah atom $\mathrm{O}$ dan Nlebih besar 10 .

Pada pengamatan ikatan obat dengan reseptor senyawa uji memiliki jumlah ikatan yang berbeda beda dan dengan asam amino yang berbeda. Kemiripan ikatan dan interaksi yang sama dengan senyawa pembanding ditemukan pada salah satu senyawa uji. Senyawa pembanding Acalabrutinib memiliki interaksi sterik dengan asam amino Ser 538 dan Leu 408 serta memiliki ikatan hidrogen dengan asam amino Ser 538, Asp 539, Met 477, Glu 475 dan Thr 474. Senyawa uji yang memiliki interaksi sterik dan ikatan hidrogen yang sama dengan senyawa pembanding Acalabrutinib yaitu 1-Benzil-3-(3-- $\mathrm{CF}_{3}$ - benzoil)urea, pada interaksi sterik terdapat asam amino Ser 538 serta ikatan hidrogen dengan asam amino Ser 538, Asp 539 dan Thr 474. Senyawa uji 1-Benzil-3-(3-- $\mathrm{CF}_{3}$ - benzoil)urea diprediksi memiliki mekanisme kerja yang sama dengan senyawa pembanding Acalabrutinib.

Pada uji korelasi diperoleh hasil sebagai berikut:

1. $\sigma$ Hammet berpengaruh secara signifikan pada $p<0,01$ terhadap bioavailabilitas dengan nilai korelasi Pearson-0,773 dengan signifikansi 0,000dan juga berpengaruh signifikan pada $p<0,05$ terhadap toksisitas dengan nilai korelasi Pearson0,481 dengan signifikansi 0,032 .

2. Es Taff berpengaruh secara signifikan pada $p<0,05$ terhadap bioavailabilitasdengan nilai korelasi Pearson 0.447 dengan signifikansi 0,048 dan Es Taft juga berpengaruh siginifikan pada $p<0,05$ terhadap aktivitas dengan nilai korelasi Pearson 0,551 dengan signifikansi 0,012 .

Hipotesa diuji dengan menggunakan analisis regresi secara linier. Hasil yang didapat lebih obyektif yaitu berupa persamaan yang lebih mudah dipahami. Regresiyang dilakukan yaitu satu parameter, dua parameter dan tiga parameter variabel bebas sifat fisikokimia dengan variabel tergantung bioavailabilitas, aktivitas dan toksisitas.

Dari uji regresi satu parameter, dua parameter dan tiga parameter terhadap parameter bioavaibilitas (F) diperoleh satu persamaan terbaik. Dapat disimpulkan persamaan terbaik ditunjukkan melalui persamaan hasil uji regresi terhadap tiga parameter. Pemilihan parameter tersebut berdasarkan dari nilai $\mathrm{R}$ dan nilai signifikan dari masing-masing persamaan. Persamaan yang terbaik yaitu harus memiliki nilai $P$ (probability) atau signifikansi kurang dari $p<0.05$, nilai $r$ mendekati satu, nilai SE (Standart Eror) paling rendah dan $\mathrm{F}$ yang tinggi dari masing-masing persamaan. Jadi parameter bioavaibilitas dipengaruhi oleh parameter sifat 
fisikokimia (lipofilik, elektronik, dan sterik) sehingga untuk mendapatkan bioavaibilitas yang optimal, perlu dilakukan tinjauan terhadap parameter sifat fisikokimia lipofilik ( $\pi$ Hansch dan $\pi^{2}$ Hansch), elektronik ( $\sigma$ Hammet) dan sterik (Es Taff).

Dari uji regresi satu parameter, dua parameter dan tiga parameter terhadap parameter aktivitas (RS) yang diperoleh persamaan terbaik. Dan dapat disimpulkan persamaan terbaik ditunjukkan pada persamaan satu parameter. Persamaan yang terbaik yaitu harus memiliki nilai signifikansi paling rendah, nilai $R$ mendekati satu, nilai SE paling rendah dan mempunyai nilai $\mathrm{F}$ yang paling tinggi. Jadi parameter aktivitas dipengaruhi oleh parameter sifat fisikokimia (lipofilik, elektronik, dan sterik) sehingga untuk mendapatkan nilai aktivitas yang optimal, perlu dilakukan tinjauan terhadap parameter sifat fisikokimia sterik (Es Taft).

Dari uji regresi pada satu parameter, dua parameter dan tiga parameter terhadap parameter toksisitas (LD50) dapat disimpulkan persamaan terbaik yang ditunjukkan melalui hasil uji regresi satu parameter. Persamaan yang terbaik yaitu harus memiliki nilai signifikansi paling rendah, nilai $R$ mendekati satu, nilai SE paling rendah dan mempunyai nilai $F$ yang paling tinggi. Jadi parameter toksisitas dipengaruhi oleh parameter sifat fisikokimia (elektronik) sehingga untuk mendapatkan nilai toksisitas yang optimal, perlu dilakukan tinjauan terhadap parameter sifat fisikokimia elektronik ( $\sigma$ ).

Dari data uji yang telah di analisa maka dapat diinterpretasikan senyawa uji yangpaling potensial untuk dilanjutkan ke tahap berikutnya sebagai terapi antikanker limfoma nonhodgkin adalah 1-Benzil-3-(3-CF3-benzoil)urea. Senyawa uji 1-Benzil-3-(3- CF3-benzoil)urea diprediksi memiliki nilai bioavaibilitas yang lebih baik dibandingkan dengan senyawa pembanding yaitu Acalabrutinib, senyawa 1-Benzil-3-(3-CF3- benzoil)urea memiliki selisih nilai bioavaibilitas yang tidak terlalu jauh dengan senyawa pembanding. Acalabrutinib memiliki nilai biavaibilitas intestinal absorbtion (Human) 94,184 \% sementara senyawa uji 1-Benzil-3-(3-CF3benzoil)urea memiliki nilai bioavaibilitas intestinal absorbtion (Human)89,906\%. Untuk hukum lima Lipinski, senyawa uji 1-Benzil-3-(3-CF3-benzoil)urea sudah memenuhi persyaratan dan di prediksimampu untuk menembus membran dengan baik dan memiliki mekanisme kerja yang sama dengan Acalabrutinib, karena memiliki interaksi sterik dengan asam amino Ser 538 serta ikatan hidrogen dengan asam amino Ser 538, Asp 539 dan Thr 474 yang sama dengan senyawa pembanding Acalabrutinib yang diperoleh menggunakan program Molegro Virtual Docking5.5 pada bagian Ligand map.

Berdasarkan Toksisitas, senyawa uji yaitu 1-Benzil-3-(3-CF3-benzoil)urea mempunyai nilai kelas toksisitas 5 dengan nilai LD50 $3000 \mathrm{mg} / \mathrm{kg}$ lebih tinggidibandingkan dengan senyawa pembanding yaitu Acalabrutinib yang mempunyai nilai kelas toksisitas 3 dengan nilai LD50 135 $\mathrm{mg} / \mathrm{kg}$. Sehingga senyawa uji 1-Benzil-3-(3-CF3- benzoil)urea lebih aman di bandingkan dengan senyawa pembanding Acalabrutinib. Dilihat dari prediksi aktivitas, senyawa 1-Benzil-3-(3-CF3benzoil)urea memiliki aktivitas yang cukup tinggi yaitu $-103,9030 \mathrm{kkal} / \mathrm{mol}$ dibandingkan dengan senyawa pembanding Acalabrutinib yaitu $-154,1513 \mathrm{kkal} / \mathrm{mol}$. Berdasarkan dari semua hasil nilai senyawa uji, untuk senyawa 1-Benzil-3-(3-CF3-benzoil)urea merupakan senyawa yang memiliki nilai aktivitas tertinggi, dan dilihat dari semua aspek uji yang telah dilakukan pada penelitian ini senyawa 1-Benzil-3-(3-CF3-benzoil)urea adalah senyawa yang paling potensial untuk di kembangkan ke tahap yang lebih lanjut.

\section{SIMPULAN}

Diperoleh hubungan nonlinier antara sifat fisikokimia, parameter lipofilik, elektronik dan sterik terhadap prediksi bioavailabilitas dari senyawa 1-benzil-3-benzoilurea dan analognya yang ditunjukkan oleh persamaan bioavailabilitas terbaik yang diperoleh yaitu $\mathrm{F}=-$ $1.969 \pi^{2}+0.851$ Es Taft $-6.116 \sigma+3.620 \pi+90.809$ dengan nilai $r=0.936 ; \mathrm{SE}=0.88289 ; \mathrm{F}=$ 26.703; $\mathrm{Sig}=0,000$ dan $\mathrm{n}=20$.

Diperoleh hubungan linier antara sifat fisikokimia, parameter lipofilik, elektronik dan sterik terhadap prediksi aktivitas dari senyawa 1-benzil-3-benzoilurea dan analognya yang ditunjukkan oleh persamaan aktivitas terbaik yang diperoleh yaitu RS $=4.376$ Es Taft -88.802 
dengan nilai $r=0.551 ; \mathrm{SE}=5.00450 ; \mathrm{F}=7.851 ; \mathrm{Sig}=0.012$ dan $\mathrm{n}=20$.

Diperoleh hubungan linier antara sifat fisikokimia, parameter lipofilik, elektronik dan sterik terhadap prediksi toksisitas dari senyawa 1-benzil-3-benzoilurea dan analognya yang ditunjukkan oleh persamaan toksisitas terbaik yang diperoleh yaitu LD50 $=672.518 \mathrm{CMR}$ 669.385 ClogP - 813.806 dengan nilai $r=0.547 ; \mathrm{SE}=445.27976 ; \mathrm{F}=3.63 ; \mathrm{Sig}=$ 0.049 dan $\mathrm{n}=20$.

\section{SARAN}

Senyawa 1-Benzil-3-(3-CF3-benzoil)urea berpotensi untuk ke tahap lebih lanjut,yaitu dengan melakukan sintesis dan uji in vitro dan in vivo pada kanker limfoma non- Hodgkin.

Dari persamaan terbaik yang didapat dapat dikembangkan untuk memodifikasi turunan yang lain dari senyawa induk 1-Benzil-3-Benzoilurea yang mempunyai aktivitas lebih tinggi disertai bioavaibilitas yang tinggi dan toksisitas yang rendah.

\section{PUSTAKA ACUAN}

American Cancer Society. (2017). Lymphoma Cancer.

Anwar, A. D., Harsono, A. B., Sasotya, R. S., Amarullah, M. N., \& Hidayat, D. (2013). Bandung Controversies and Consensus in Obstetrics \& Gynecology.

Arruebo, M., Villaboa, N., Saez-Gutierrez, B., Lambea, J., Tres, A., Valladares, M., \& GonzalezFernandez, A. (2011). Assessment of the Evolution of Cancer Treatment Therapies. Cancers.

Astor, L. (2019, 11 21). FDA Approves Acalabrutinib for CLL/SLL. Retrieved from Targeted Oncology: https://www.targetedonc.com/news/fda-approves-acalabrutinib-for-cllsll

Drugbank. (2016, Oktober 20). Acalabrutinib. Retrieved Januari 10, 2020, from Drugbank: https://www.drugbank.ca/drugs/DB11703

Ferreira, L. G., Dos Santos, R., Olivia, G., \& Andricopulo, A. (2015). Molecular Docking and Structure-Based Drug Design Strategies. Molecules, 13384-13421.

Kemenkes RI. (2015). Data dan Kondisi Penyakit Limfoma. InfoDATIN.

Globocan. (2018). Cancer Today. Retrieved September 2019, from International Agency for Research on Cancer: http://gco.iarc.fr/today/data/factsheets/populations/900world-fact-sheets.pdf

Koda-Kimble, M. A., Alldredge, B. K., Young, L. Y., Corelli, R. L., Guglielmo, B. J., Kradjan, W. A., \& Williams, B. R. (2008). Applied Therapeutics The Clinical Use of Drugs.

National Cancer Institute. (2019, June 14). Adult Non-Hodgkin Lymphoma Treatment (PDQ $\left.{ }^{\circledR}\right)$-Patient Version. Retrieved July 2019, 26, from National Cancer Institute: https://www.cancer.gov/types/lymphoma/patient/adult-nhl-treatment-pdq\#_190 